\title{
Education for development in the context of various theoretical approaches within educational sciences ${ }^{1}$
}

\begin{abstract}
The concept of education for development has been - next to other educational concepts - subject to many attempts of redefinition, which are often determined by different pragmatic and ideological postulates. Therefore, it is possible that this highly important concept is partially becoming its own antithesis. That is why the paper analyses education for development through different theoretical approaches which have been established during the course of development of educational sciences. In this way, education for development is seen through basic tenets of Normative Educational Sciences, Empirical Educational Sciences, Humanistic-Scientific Pedagogy, Critical Educational Sciences and Systems Theory. In addition to this, integrated pedagogical review of education for development is observed through confluent education theory. Within this theory, the concept of education for development is based on education as a human (individual) need, and only after that education as social need.
\end{abstract}

Keywords: education for development, theoretical approaches, Educational Sciences, confluent education, individual need, social need.

\section{Edukacja dla rozwoju w świetle różnych podejść teoretycznych w naukach o wychowaniu}

\begin{abstract}
Abstrakt
Koncepcja edukacji dla rozwoju, obok innych podejść do wychowania, podlega wielu próbom redefinicji. Wynika to z przesłanek odmiennych pragmatycznie i ideologicznie. Jest zatem możliwe, że ta niezwykle ważna koncepcja stanie się częściowo swoją
\end{abstract}

\footnotetext{
* Department of Pedagogy and Psychology, Faculty of Humanities and Social Sciences, University of Tuzla Bosnia and Herzegovina.

1 This article is the author's revised and upgraded version of the article published in 2014 in Bosnian under the title: Obrazovanje za razvoj u kontekstu različitih teorijskih pravaca znanosti o odgoju, „Zbornik radova Islamskog pedagoškog fakulteta u Zenici” 2014, no. 12: 77-98. The editors of the journal "Educational Sciences Interdisciplinary Studies" would like to thank the Editorial Board of Proceedings of the Islamic Pedagogical Faculty of the University of Zenica for agreeing to publish the text in English.
} 
antytezą. W związku z powyższym analizuję $\mathrm{w}$ tym artykule modele edukacji dla rozwoju zgodnie z wyłanianiem się w pedagogice różnych teorii. Możemy je postrzegać jako teorie normatywne w naukach pedagogicznych jako lokujące się w pedagogice duchowej (pedagogice kultury), osadzone w pedagogice krytycznej czy teorii systemowej. Ukazuję także w swojej analizie edukację dla rozwoju jako teorię kształcenia holistycznego. W jej ramach pojęcie edukacji dla rozwoju łączy w sobie kształcenie indywidualności z uspołecznieniem jednostki.

Słowa kluczowe: edukacja dla rozwoju, teorie wychowania, holistyczne kształcenie, kształcenie osoby, uspołecznienie.

\section{Introduction}

Different approaches to education as socially organized activity (structural functional, conflicting, liberal, interactionist and neoliberal points of view) indicate that education, with all its visible as well as invisible functions, enables people to participate in every aspect of social life and work, to acquire knowledge and skills which are important and necessary in the modern world, but, at the same time, they indicate the fact that education serves as the main domain and mechanism for reproducing social inequalities².

All this prompts us to put more emphasis on what should be called education for development as a category of Educational Sciences, alongside all necessary interdisciplinary reviews and attempts at defining education for development. Within modern attempts at understanding education in general, and education for development in particular, especially significant is accepting the meaning of this concept as a part of Educational Science which should enable integration of basic pedagogical assumptions in the interdisciplinary connection between education and overall human development. Below, we will try to explain the meaning of the concept of education for development as one of the fundamental concepts in educational science, while bearing in mind different approaches developed during the history of Educational Science ${ }^{3}$.

\section{Education for development in the context of the normative approach within Educational Sciences. What should education for development be like?}

In the formal disciplinary sense of this term, pedagogy or Educational Science was developed as a normative discipline on the basis of J. F. Herbart's philosophical views. A starting point for this approach is the fact that the goal of Educational

\footnotetext{
2 For more details, see the following: Bourdieu P. (1996), Browne K. (1998: 317-344), Freire P. (2000), Haralambos M., Holborn M. (2000), Bilton T. at al. (2002).

3 For more details about those approaches, see the following: Köning, Zedler (2001).
} 
Science is offering instructions for pedagogical and educational work, which implies their reduction to reliable principles and standards (Köning, Zedler 2001). Therefore, in the spirit of this approach, there is no pedagogical work or education without universal values and principles. Thus, development of the individual and the society contributes to the acknowledgment of norms and values which preserve the "form" of a human (individual) who educates himself/herself and a type of society that makes that understanding possible. "Concepts of pedagogy as a science based on principles do not have a goal to explore pedagogical and educational reality, but to systematize thoughts about principles that people should follow in their (pedagogical) work" (Lenzen 2002: 141). Procedures and goals of education for development, accordingly, might be standardized according to Herbart's "practical ideas".

There is firstly presented 'Idea of Inner Freedom', which is described as education for development in the context of individual and social processes. This idea contributes not only to realization of human freedom, the so called limitless freedom. It also implies freedom which measures humanity and human behavior. That is why education for development should give each individual an opportunity to choose freely between different paths based on their distinctive idiosyncrasies and competences. This kind of freedom achieved through education is in anthropological and pedagogical sense a natural norm, i.e. a principle within individual's natural right to education, freedom of social activity and development that is indicated by the previously mentioned terms.

The 'Idea of Perfection' is mentioned as education achieved through development of the individual and the society. It designates a constant flow and differentiation of the overall human development possibilities, i.e. when "every individual strives toward continuous improvement" (Köning, Zedler 2001: 21).

The 'Idea of Benevolence' implies acquiring knowledge that the individual uses to bring about kindness and benevolence towards the others. These traits are not simply the aim of education for development, but they also represent its essence. Otherwise, it might be assertable that "being educated and being good automatically do not concur" (Lenzen 2008: 18).

In Herbart's 'practical ideas' we read about the 'Idea of Justice'. It is about the right of every person to education. That is why education for development should be determined by a demand that a right to education cannot be relativized. It has been relativized by artificially created inequalities between individuals and societies (here, naturally, we do not refer to natural differences which are a part of our „colorful" world) or by modern ideology of technological development and, as Harmut von Henting said "scientific magic" (Henting 2007: 23).

In the context of the Idea of Equity, education in its essence leads to "connection between doing and wanting" (Köning, Zedler 2001: 21). In case of the opposite situation, education cannot be discussed, therefore education for development also cannot be discussed. The normative and disciplinary concept of education for 
development presupposes that behavior depends on knowledge. As a result, pedagogical work is like a link that connects knowledge and behavior.

On the other side, normative approach to pedagogical work and education was developed by Derbolav. Moreover, Benner sets up four principles of pedagogical practical work despite the fact that he did not develop guidelines for practical pedagogical work based on supreme norms. Bearing in mind Benner's four principles, education for development in pedagogical practice implies (Gudjons 1994: 147):

1. Human education with the purpose of productive freedom;

2. Demand for self-activity (because the first principle is developed exclusively by the participation of those who are growing up, i.e. those who are educated;

3. Transmission of social determinism (pedagogical practice) to pedagogical determinism (i.e. social influence must be pedagogically tested, controlled, corrected);

4. All human practices should have one common task - further development of humanity.

The first two principles refer to individual, and the other two refer to social aspect of education for development. Also, the first and fourth principle refer to tasks and purpose of practicing education for development within the framework of overall human practice, while the second and third principle refer to favorable procedures within education for development relating to individual and social influence on pedagogical work and education (Gudjons 1994: 147).

Acknowledging normative educational science in current debates on education for development, and bearing in mind Brenner's four principles, enable us to at least notice and understand - if they do not enable us to prevent - endless possibilities that occur within many modern inconsequential instrumentalizations of pedagogical thought and educational work in the field of education for development.

\section{Education for development in the context of the empirical approach within Educational Sciences: how to nomologically explain education for development?}

The empirical approach within Educational science was, in its beginnings, based on an attempt to develop Educational science modeled on natural sciences. Such Educational science would question facts in the field of pedagogical work and education in order to establish nomological knowledge. Reviewing the concept of education for development and taking into account the most important principles of empirical approach contribute to scientific research. We analyze the most important objective facts within reviews of general education and in particular education for development. What does that mean today? As it has been said, a lot is expected from education today. Investing in education is classified as an essential 
investment in a particular society. Modern society has over the past few decades been called the "knowledge society" and/or the "learning society" which vividly proves that society's survival and development (especially the so-called sustainable development) is contingent upon education and learning. It is necessary to mention that these concepts may be subjects to serious and justified criticism 4 .

Independently, the functioning of a modern individual or society and thought on their future are problems that are directly and indirectly related to education. That also suggests significant investments, especially in the field of education, which enables development in the broadest sense of the word. On the other hand, modern education is marked by numerous changes, reforms or thoughtless experiments, or maybe overturns, as Liessman points out when he says that today's reformers basically do not bring about reforms, but overturns (Liessman 2006). He also says that only a very rich or very stupid country can afford to make up a new architecture of studying for every generation of students because chaos will bring about new reforms (Liessman 2006). Indeed, is it possible to develop the concept of education for development based on too expensive, often suspicious projects made and led by different power centers; projects that consist of simple "workshops", stories about "excellence", "quality", "indicators of excellence and quality", and "learning outcomes" (?!). Insistence on those untested and often scientifically unproven ideas casts a shadow on real educational needs and necessary activities that could fulfill those needs. In the age of constant crisis, including the current economic crisis, there is much opposition to educational techniques that seem "unproven" or "too experimental". This means that taxpayers are not willing to give more money for programs and educational activities which have not been proven yet.

In the light of the facts that have been explained, the concept of education for development in the context of empirical Educational Science is necessarily based on independent (we could say "pure") scientific research of pedagogical and educational issues and facts. Those researches can bring nomological knowledge about the most significant traits of education for development, starting from scientific research of real (and not artificially made) educational needs. They explain the most significant factors of education for development, but also visible and invisible barriers to education set up by today's unrestrained world, as Giddens calls it. In other words, today's world of virtual reality needs empirical (critical and rational) comprehension of education, in order to preserve it among numerous reforms and attacks, and to keep it a significant development factor. Empirical research and theories of modern education that can be subjectively tested should provide

\footnotetext{
4 Here, we will not deal with the meaning of the abovementioned concepts of knowledge society and "learning society", or with what makes them important and what could be the basis for criticism. We will only mention that different relations could be established between those concepts, from equalization, juxtaposition to mutual exclusion (lately, it has been said that the knowledge society cannot simultaneously be the learning society). For more details, see the following work by Konrad Paul Liessman (2006).
} 
a significant part of the answer to a question "What kind of education do we actually need and want?" (Henting 2008: 13) in today's world filled with contradictions.

Besides, that approach to education for development is also necessary to determine those characteristics that separate education from other human activities, as Brezinka wanted (Lenzen 2002). This can raise a provocative question: are empirical and scientific explanations unnecessary in today's world of superficial experiences, to determine a difference between certain procedures in education and, for instance, certain activities in show business, on the stage or on the circus floor.

The basic principles of empirical Educational Science are necessary when discussing education for development in order to preserve the essence of science in Educational Science, and to preserve rational basics of education, an exceptional human activity that cannot be reduced to current political (in the so-called countries in transition political can be understood as populist or antiscientific) techniques, styles and crazes.

\section{Education for development in the context of humanistic-scientific pedagogy: hermeneutics of education for development}

Humanistic-scientific pedagogy is an approach in Educational Science developed on the basis of Dilthey's foundation of spiritual sciences and it was a kind of opposition to the empirical approach. Basic methodological paradigm of humanistic-scientific pedagogy was understood, not explained, i.e. the basic method for this approach is hermeneutical method (hermeneutical circle). That method refers to "pedagogical reality as a practical field of 'pedagogical acts'. They should be understood and explained within their meaningful content" (Gudjons 1994: 30).

Therefore, humanistic-scientific pedagogical aspect of education for development implies detecting, understanding and explaining the internal sense of this concept of education from itself, not from something outside of this concept. Humanistic-scientific pedagogy (humanist pedagogy) teaches us, in the spirit of Dilthey's definition of Educational Sciences, that education for development is an activity which "forms spiritual life" of the individual. Therefore humanisticscientific understanding of education for development "is not thinking in category of necessity, instead it is a battle" (Lenzen 2002: 169).

At the time of different attempts at deconstructing many human cultural and spiritual achievements, humanistic-scientific tradition within Educational Sciences encourages us to question the essence of education for development in order to understand replaceability of education, and also the essence of human individual and social development that occurs in every age. This understanding of education for development enables us to structure it in a way that does not direct all attention to "preparation for the future"; but accentuates that the goal of education for 
development is also directed to the present (which also implies (presupposes) the past that precedes) where "now and here" occurs in a form of a "pedagogic relationship" as a passionate relationship between "a mature human and a human in making because of himself, to accomplish his own life and its form" (Gudjons 1994: 32). Thus, education for development does not become questionable and changeable due to our focus on the uncertainty of the future and its unpredictability. It is good to anticipate the future and development by using education, but is it possible to miss the right path because of our focus on the goal? How to determine the goal of education, if education itself is the goal? Constant orientation on the needs of future development can cast a shadow on current education as a goal, so it could happen that the target is hit and everything else is missed, as had been said by Hegel.

Humanistic-scientific pedagogy highlights that education for development is a human activity which has its inner sense and spiritual and cultural logic. Thereby, it is seen as a part of social, political, economic and cultural development, i.e. it is observed in the light of historical relations between those different factors. As such, it also has a substance of its own distinctive activity. Its creation is contributed by autonomous (independent) historical and pedagogical conscience or autonomous educating or educated conscience.

\section{Education for development in the context of Critical Educational Science: what education for development should not be?}

The Critical Educational Sciences originated in an attempt to "transfer" basic theoretical postulates of critical social theory into the field of pedagogical work and education. The basic methodological model used in this approach is criticism of the ideology that should set forth and reveal different ways of ideological subdual of pedagogical work and education, in order to achieve self-determination, solidarity, maturity and emancipation, i.e. liberating humans of unnecessary discipline and rule of the others. Education for development, observed in the tradition of Critical Educational Sciences, is considered a human activity, individual need and social need that is carried out with the emancipative interest in the first place. That means that it cannot contain means for manipulating or means of unnecessary repression over people.

Many analyses of modern reforms and educational structures on all levels have shown what is behind those reforms, especially in the so-called countries in transition - usually those are not emancipative interests of the individual and free society; but new aspects of economic and neoliberal demands which refer to public service branding, and therefore "education branding", and in a particular way "university branding" (Klajn 2003). Let us pay attention to some of those analyses: Hill (2003) deems that education reforms can be observed as "part of the ideologi- 
cal and policy offensive by neo-liberal Capital", while privatization of public services, capitalization and commodification of humanity and global rules set by international financial organizations precede the reform. Also, Whitty, Power and Halpin (Hill 2003) conclude that one of the results of marketization of education is the increase or decrease of racial discrimination in schools.

The market is deepening the existing inequalities It is visible not only on the racial level, but on the social level, too. "On an international level, World Bank and IMF dictates have resulted in the actual disappearance of formerly free nationally funded health and education services" (Hill 2003). Hatcher and Hirt (1999) write about public invitations from economic and political organizations to carry out fast education reform to satisfy the needs of new global "knowledge - based economy". Thereby, globalization is constructed as unrelenting powerful change that everyone needs to adapt to and become a flexible workforce. Accordingly, basic postulates of Critical Educational Sciences teach us what education for development should and should not be (Lenzen 2002). It is, hence considered a "space" liberated of different ideological influences of interest groups that, by using the form of education, aspire toward the goals that do not respond to the nature of pedagogical and educational process, and in that way, they make distorted conscience equal to human need.

\section{Education for development in the context of systems theory: the importance of education for development as a subsystem of educational and social system}

General systems theory, as well as sociological systems theory, have transferred new approaches to social phenomena into Educational Science, next to new conceptual categories. Those new approaches enable us to observe education as a separate system with all the characteristics that make up the system (group of elements and their interrelation, restrictiveness towards environment, hierarchical segmentation, emergence, striving for balance). That puts special emphasis on organizational, i.e. social character of education as a purposely organized activity. Education for development represents a special system, actually a subsystem of educational and social system. This means that it is an activity which should be seriously and carefully organized and directed. Ever since the beginning of the nineteenth century, many developed countries have considered educational system as a central social institution.

Education has always been a field of different influences and activities. It has for a long time been a political battlefield, as it is today, at the beginning of this new age (Giddens 2001). Current educational systems are characterized by different occurrences and issues that sociologists discuss in their "systemic" considerations of education (Thio 1992; Schaefer, Lamm 1992; Hess, Markson, Stein 1993; Macionis 1995; Browne 1998; Haralambos, Holborn 2002; Giddens 2001; Macionis, 
Plummer 2002; Bilton at all 2002). Some of them are the following: the end of the twentieth and the beginning of the twenty-first century is characterized by educational pluralism. This pluralism is followed by large-scale decentralization of educational systems; decline of educational systems below university level is evident everywhere - that does not mean that educational systems are not declining on a university level; instead, it means that a wider "autonomy" of educational system is present on this level and therefore there is more "resistance" to system homeostasis. Dissemination of universities is also evident, and students' age limit is increasing.

There is an interesting worldwide phenomenon that elite universities have become less attractive for businesses and governments, and that attractiveness now belongs to more open universities. Technology is transforming educational systems more; today's educational systems are organized bureaucratically and main bureaucratic elements are visible. Financing is one of the most significant current problems of educational systems and higher education in many countries is going through finance crisis. Lack of educational policies which regulate educational systems is visible and it results in the loss of equality, loss of economic and social justice, loss of democracy and democratic responsibility, and loss of critical thinking. Educational systems are constantly subject to criticism - as a result of criticism, attempts have been made at improving standards, by better connection between different elements of educational system and their better organization in order to satisfy the needs that society has. Educational systems can be a major force in stimulating social changes. Such systems in complex societies are also responsible for the goals of a given society and collective progress. All those occurrences in the field of educational systems unavoidably influence social organization of education for development. Is it not true that the term education for development is partially conceived as a result of occurrences and issues that education systems worldwide have encountered?

From the point of view of systems theory, the concept of education for development should be embedded into all elements and parts of educational system from elementary level to university level. It can also alleviate many breaks which occur within the educational and social system. That way, education for development makes discord in educational and social hierarchy more stable. In other words, by carefully designing and administrating education for development, the synergistic property of educational and social systems, as well as their emergent property, are increased.

Following the analysis of education for development and bearing in mind the main postulates of different approaches within Educational Science, it seems appropriate to make a pedagogical review of this educational concept by using the theory of confluent education. 


\section{Education for development in the context of the Confluent Theory of Education: development of specific human characteristics and human vitality}

The Confluent Theory of Education is particularly significant and inspiring for understanding education as one of basic pedagogical categories. This theory classifies confluent education as a

socially organized process of learning and teaching, whereby biological entity and/or individual instinctive being, by using educational means, (self-)activity, and improving and encouraging factors, develops from internal flow of growth/education into a whole and unique mental, spiritual and active being. It is a way of integrating social, cognitive, affective, voluntary and motivational components of human development (Slatina 2005: 89).

Bearing in mind this definition of education as confluent process, education for development can be understood as a process of developing free, responsible, sociable and self-actualized being which is upon birth still not what it should be, and which is not in its essence "finished and done" but "assigned". That way, education for development intertwines sociocultural (enculturation/acculturation), psychosocial (socialization/internalization), biopsychological (differentiation/ integration) and intrapsychological processes (individuation/personalization). Education for development as a confluent process weaves together different elements of the aforementioned processes and makes those elements stronger (Slatina 2005).

Further, observing the concept of education for development within the Confluent Theory of Education contributes to noticing the difference between authentic and instrumental (institutionalized) education, and therefore the difference between education and schooling. Education for development should not be entirely reduced to schooling, and especially not to schooling that favors just one sphere of human activity (e.g. cognitive sphere) at the expense of other spheres (emotional, voluntary and active) (Slatina 2001). In the pedagogical approach, education for development is considered as a primarily individual human need, and only after that a social need; it is considered a process which develops, i.e. establishes specific human traits and human vitality (capability of perception and observation, thinking, remembering, feeling, volition, imagination and others); so this is "education for human being itself ... its purposes are quality changes in cognitive, affective, voluntary and social field of human life" (Slatina 2005: 89). This intellectualization of education for development has been derived from "human natur", from anthropology, from the essence of upbringing, and not from something outside of it, e.g. from economy, politics or ideology. Therefore, the theory of confluent education and the corresponding confluent model of education for development presuppose the following (Slatina 2001: 90): 
- teaching the youth to realize and accomplish their possibilities, and not to use their possibilities constrainedly;

- enabling them to have an open mind, as opposed to intolerant and rigid conscience;

- securing a development of feeling and need for freedom and personal dignity, not adjusting them to obedience and subservience;

- teaching them how to think, to work, to evaluate and believe, not teaching them to think within appropriate framework;

- teaching them to be independent and to freely express their opinion, not teaching them to be dependent on someone else's opinion;

- offering them ideas, not ideology and manipulation;

- pointing out a possibility of choice, not abolishing every alternative;

- teaching them to use verified information, and not teaching them to (mis)use all information;

- sensibly influence the behavior of children and young people, not condemning them senselessly;

- demonstrating mutual teaching, not teaching power relationship.

Basic postulates of the theory of confluent education particularly point out the fact that education for development is primarily internal, individual process of human development which takes place through constant transformation of human possibilities and capabilities, i.e. that it is a process which always, even when dealing with cruel, artificially made constructions of human society, retains the characteristic of authentic Educational Science. Of course, this does not contest the fact that humans are social beings, but it is associated with the fact that education is a social need from the perspective of self-actualized individual, who is at the same time an active social being.

\section{Overview}

An analysis of the concept of education for development in the context of different approaches within Educational Science demonstrates the most significant contours of what should this concept represent, it offers a nomological starting point for its explanation, as well as main hermeneutical starting points for understanding the essence of this concept. It gives warnings of what should not be considered education for development and points to its significance and meaning as one of subsystems within the educational and social system. It also accentuates confluency as a prominent pedagogical characteristic of education for development.

All of the above enables us to notice and understand issues that occur within the field of education for development as a result of modern instrumentalizations of Educational Science which devoid it of its values. There is a need to preserve rational (scientific) basis of education for development as an important human 
activity, to accentuate the significance of autonomous pedagogical (educational) conscience in designing this concept of education. Moreover, in this light it is needed to prevent different ideological and interest-motivated influences and transforming education for development into a field for equalization of distorted conscience with human need.

A systemic design of education for development increases synergic capacity of educational and social system; it makes it possible for an individual to develop a free and self-activating personality which contributes to the society. That way, the essence of education is particularly accentuated and "preserved" within this concept, which considers it a natural right of every human being. This is why it is significant for actual education to take place within education for development.

\section{References}

Bilton T., Bonnett K., Jones P., Lawson T., Skinner D., Stanworth M., Webster A. (2002) Introductory Sociology, Fourth edition, New York, Palgrave Macmillan.

Bourdieu P. (1996) Distinction - A Social Critique of the Judgement of Taste, London, Routledge.

Browne K. (1998) An introduction to Sociology, Second edition, Cambridge, Polity Press.

Freire P. (2000) Pedagogy of the Oppressed, New York/London, Continuum.

Giddens E. (2001) Sociology, Cambridge, Polity Press.

Gudjons H. (1994) Pedagogija: Temeljna znanja [Basic knowledge pedagogy], Zagreb, Educa.

Haralambos M., Holborn M. (2000) Sociology: Themes and Perspectives, Fifth edition, London, Harper Collins.

Hatcher R., Hirtt N. (1999) The Business Agenda Behind Labour's Policy in: Business, Business, Business, A. Martin at all. (eds.), New Labour's Education Policy: 12-23.

Henting H. (2007) Kakav odgoj želimo? O odgoju za 21. stoljeće [Ah, the values! About an Education for the 21st century], Zagreb, Educa.

Henting H. (2008) Što je obrazovanje. Esej [Education: an Essay], Zagreb, Educa.

Hess B. B., Markson E. W., Stein P. J. (1993) Sociology, Fourth edition, New York, Macmillan Publishing Company, Inc. 
Klajn N. (2003) Ne logo [No logo], Beograd, Reč.

Köning E., Zedler P. (2001) Teorije znanosti o odgoju. Uvod u osnove, metode $i$ praktičnu primjenu [Theories of Educational Science: Introduction to the fundamentals, methods and practical applications], Zagreb, Educa.

Lenzen D. (2002) Vodič za studij znanosti o odgoju [Guide for the study of the educational science], Zagreb, Educa.

Liessman K. P. (2006) Theorie der Unbildung. Die Irtümer der Wissensgesellschaft [Theory of uneducated. Misconceptions of knowledge society], Wien, Zsolnay Verlag.

Macionis J. J. (1995) Sociology, Fifth edition, New Jersey, Prentice Hall, Englewood Cliffs.

Macionis J. J., Plummer K. (2002) Sociology: A Global Introduction, Second edition, London, Pearson Education Limited.

Schaefer T. R., Lamm R. P. (1992) Sociology, Fourth edition, New York, McGRAW-Hill, Inc.

Slatina M. (2001) Škola između odgoja kao ljudske i odgoja kao društvene potrebe [School between Education as Human Need and Education as Social Need], "Zbornik Radova Behram-Begove Medrese", 3/4: 65-90.

Slatina M. (2005) Od individue do ličnosti - Uvođenje u teoriju konfluentog obrazovanja [A Person to A Personality - Introduction to The Theory of Confluent Education], Zenica, Dom štampe.

Thio A. (1992) Sociology: An Introduction, Third edition, New York, HarperColins Publishers Inc.

\section{Electronic sources:}

Hill D. (2003) Global Neo-Liberalism, the Deformation of Education and Resistance, "Journal for Critical Education Policy Studies", vol. 1, no 1, /on line/ downloaded from the Internet 31st July 2006. from http://www.jceps.com/?pageID=article\&articleID=7.

Linguistic consultation: Arleta Suwalska 